\title{
Intrahepatic Cholangiocarcinoma With Lymphoepithelioma-like Carcinoma Components Not Associated With Epstein-Barr Virus: Report of a Case
}

Suefumi Aosasa ${ }^{1}$, Tadashi Maejima ${ }^{1}$, Akifumi Kimura ${ }^{1}$, Kiyoshi Nishiyama ${ }^{1}$, Hiromi Edo ${ }^{2}$, Hiroshi Shinmoto $^{2}$, Tatsumi Kaji ${ }^{2}$, Sho Ogata ${ }^{3}$, Kazuo Hatsuse ${ }^{1}$, Kazuo Hase ${ }^{1}$, Junji Yamamoto $^{1}$

${ }^{1}$ Department of Surgery, ${ }^{2}$ Department of Radiology, and ${ }^{3}$ Department of Pathology, National Defense Medical College, Saitama, Japan

A carcinoma displaying undifferentiated features with dense lymphoplasmacytic infiltration is defined as lymphoepithelioma-like carcinoma (LELC). Intrahepatic cholangiocarcinoma (ICC) with LELC components is rare, and most LELCs are associated with Epstein-Barr virus (EBV). We report here on a case of ICC with LELC components not associated with EBV. A 65-year-old woman was incidentally found to have a hepatic tumor in the caudate lobe. An extended right hepatectomy with lymphadenectomy was performed. Histologically, the tumor was mainly composed of large undifferentiated epithelial cells with vesicular nuclei, prominent nucleoli, indistinct cell borders, and heavy small lymphocytic infiltration, which are the characteristic features of LELC. Immunohistochemical studies revealed that the tumor cells were positive for cytokeratin 19 but were negative for glypican 3. In situ hybridization using EBV-encoded RNA was negative. Therefore, a diagnosis of ICC with LELC components not associated with EBV was made. Because there is limited information available regarding the prognosis and treatment of ICC with LELC components because of the limited number of reported cases, additional studies will be needed to clarify the clinicopathologic features of this disease. 
Key words: Lymphoepithelioma-like carcinoma - Cholangiocarcinoma - Epstein-Barr virus Liver

L ymphoepithelioma-like carcinomas (LELCs) are tumors that are composed of undifferentiated carcinoma with an intense lymphocytic infiltrate, and they have histomorphologic features identical to those of undifferentiated nasopharyngeal carcinomas. These tumors have been reported in various anatomic sites, such as the stomach, salivary gland, and thymus. ${ }^{1}$ The occurrence of LELC in the hepatobiliary tract is rare. Most LELCs have been reported to be associated with the Epstein-Barr virus (EBV). ${ }^{1-4}$ To the best of our knowledge, only 6 cases of intrahepatic cholangiocarcinoma (ICC) with LELC components not associated with EBV infection have been reported, ${ }^{5-10}$ and only 2 cases with lymph node metastases at the time of surgery have been reported. ${ }^{5,9}$ In this paper, we report on an unusual case of an ICC with LELC components accompanied by lymph node metastases not associated with EBV infection.

\section{Case Report}

A 65-year-old woman was incidentally found to have a hepatic tumor by abdominal ultrasonography at a local hospital. Enhanced computed tomography (CT) revealed a heterogeneous liver tumor measuring 5 $\mathrm{cm}$ in diameter in the caudate lobe adjacent to the right portal branch and the inferior vena cava. CT revealed a low-attenuation mass measuring $5 \mathrm{~cm}$ in diameter in the right hepatic anterior lobe and caudate lobe adjacent to the right portal branch and the inferior vena cava. Dynamic contrast-enhanced CT showed a slightly enhanced mass in the arterial phase, which washed out in the portal and delayed phases (Fig. 1). Magnetic resonance imaging showed that the hepatic mass appeared to be hypointense on T1-weighted images and hyperintense on both T2weighted images and diffusion-weighted images (Fig. 2). The laboratory findings were as follows: hematocrit, $36.0 \%$; platelets, $208 \times 10^{3} / \mu \mathrm{L}$; aspartate aminotransferase, $25 \mathrm{U} / \mathrm{L}$ (normal $<35 \mathrm{U} / \mathrm{L}$ ); alanine aminotransferase, $20 \mathrm{U}$ (normal $<28 \mathrm{U}$ ); bilirubin, 0.4 $\mathrm{mg} / \mathrm{dL}$ (normal $<1.0 \mathrm{mg} / \mathrm{dL}$ ); albumin, $4.4 \mathrm{~g} / \mathrm{dL}$; and prothrombin time, $88.9 \%$. The indocyanine green retention rate after 15 minutes was $7.1 \%$. The findings for the serum hepatitis B virus (HBV) surface antigen were negative, whereas the patient tested positive for hepatitis $\mathrm{C}$ virus $(\mathrm{HCV})$ antibodies. Her serum carcinoembryonic antigen level was elevated, at
$10.7 \mathrm{ng} / \mathrm{mL}$ (normal $<5 \mathrm{ng} / \mathrm{mL}$ ), but the levels of other tumor markers, including alpha-fetoprotein (6.0 ng/mL; normal $<10 \mathrm{mg} / \mathrm{mL}$ ), des-gammacarboxy prothrombin (PIVKA-II; $31 \mathrm{mAU} / \mathrm{mL}$; nor$\mathrm{mal}<40 \mathrm{mAU} / \mathrm{mL}$ ), and CA19-9 (11.3 U/mL; normal $<37 \mathrm{U} / \mathrm{mL}$ ), were within the normal ranges. An extended right hepatectomy was performed, and enlarged lymph nodes that were noted in the porta hepatica were removed. The length of the operation was 7 hours and 25 minutes, and the total amount of blood loss was $499 \mathrm{~mL}$.

A $14.7 \times 14.3 \times 8.0 \mathrm{~cm}$ segment of the liver weighing $660 \mathrm{~g}$, and the enlarged lymph nodes in the porta hepatica were resected. Macroscopically, there was a $6.4 \times 4.9 \times 4.7 \mathrm{~cm}$ circumscribed, round, yellowish white, soft tumor found in the resected segment (Fig. 3). The background liver was not cirrhotic. Microscopically, the neoplasm was mainly composed of large undifferentiated epithelial cells with vesicular nuclei, prominent nucleoli, indistinct cell borders, and heavy small lymphocytic infiltration, which are characteristic features of LELC. No carcinoma cells invaded the bile duct, and the surgical margin was free. Alcian blue staining was positive in the epithelial lining. Immunohistochemically, the tumor cells were positive for cytokeratin 19, but they were negative for glypican 3 (Fig. 4). In situ hybridization using EBV-encoded RNA was negative. Based on these analyses of the resected liver mass, the patient was diagnosed with ICC with LELC components not associated with EBV. A total of 2 of the 10 resected lymph nodes revealed metastasis, which exclusively consisted of LELC components.

The patient's postoperative course was uneventful, and the patient has been free from tumor recurrence for 20 months since the surgery.

\section{Discussion}

Neoplasms with features of undifferentiated carcinoma with intense lymphoid stroma are classified as LELCs, and it has been reported that LELCs can occur in various organs, including the salivary gland $^{11}{ }^{11}$ thymus, $^{12}$ trachea $^{13}{ }^{13}$ lung, ${ }^{14}$ esophagus, ${ }^{15}$ stomach, ${ }^{16}$ urinary bladder, ${ }^{17}$ uterine cervix, ${ }^{18}$ and vagina. ${ }^{19}$ To the best of our knowledge, 8 cases of lymphoepithelioma-like hepatocellular carcino$\mathrm{ma}{ }^{20-23} 1$ case of LELC of the inferior common bile duct, $^{24}$ and 16 cases of ICC with LELC component 

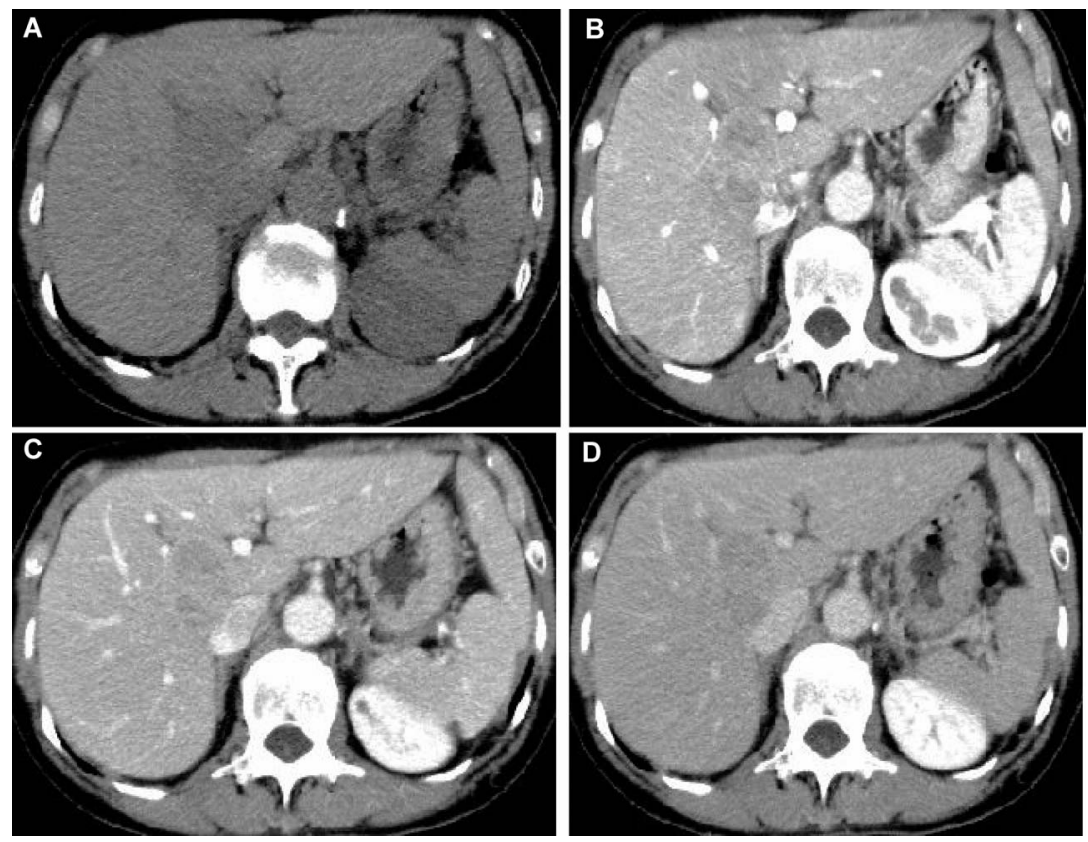

Fig. 1 CT images. (A) CT revealed a low-attenuation mass in the right hepatic anterior lobe and caudate lobe in the simple phase. Dynamic contrastenhanced CT showed a slightly enhanced mass (B) in the arterial phase, which washed out in the $(C)$ portal phase and in the (D) delayed phase. have been reported in the English literature..$^{2-10,25-27}$ In this case, the tumor cells showed positive immunoreactivity for cytokeratin 19 but no immunoreactivity for glypican 3, a useful marker of hepatocellular carcinoma. This immunohistochemical phenotype was considered to be an indicator for the diagnosis of cholangiocarcinoma. A summary of the previously reported cases of ICC with LELC components is shown in Table 1.
Like nasopharyngeal carcinomas, most LELCs are strongly associated with EBV, ${ }^{1}$ as are LELCs of the salivary gland, ${ }^{11}$ thymus, ${ }^{12}$ lung, ${ }^{14}$ and stomach. ${ }^{16}$ In contrast, EBV was not associated with LELCs observed in the oral cavity, ${ }^{28}$ urinary bladder, ${ }^{17}$ uterine cervix, ${ }^{29}$ and vagina. ${ }^{19}$ In lymphoepithelioma-like hepatocellular carcinoma, 87\% (7 of 8) of cases were EBV negative, ${ }^{20,21,23}$ and 1 case of LELC of the inferior common bile duct was also EBV
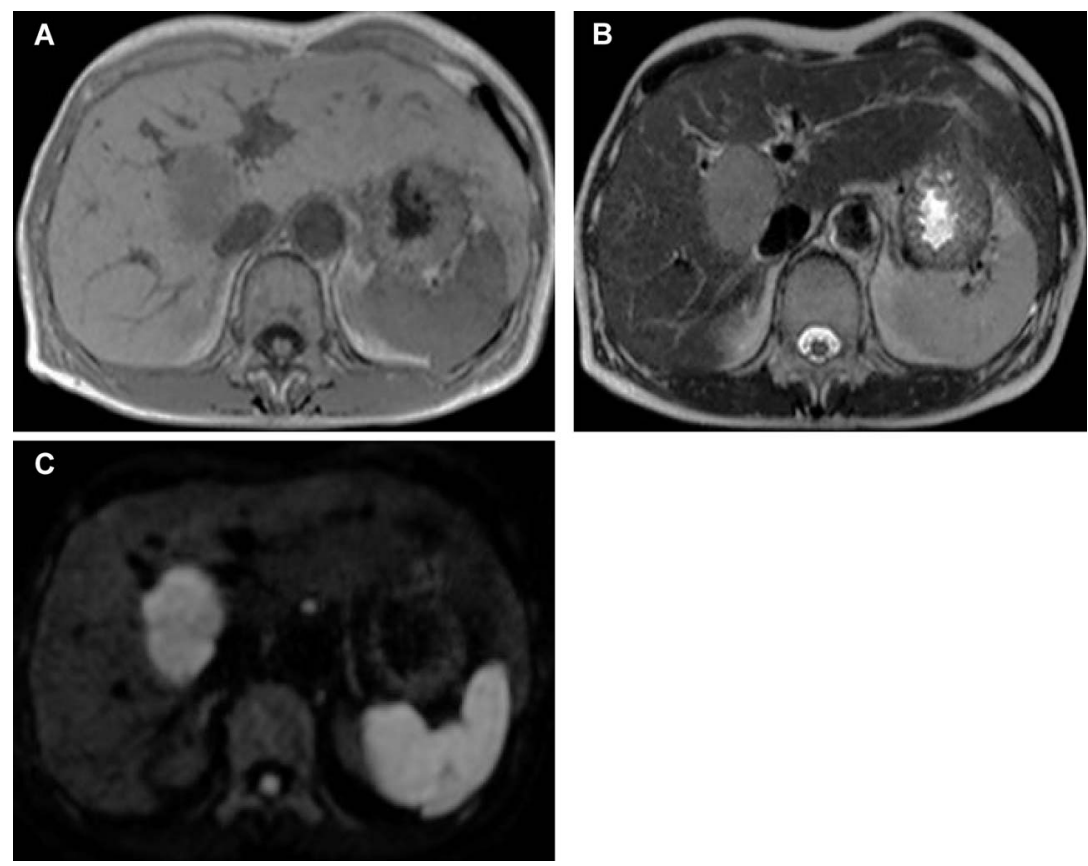

Fig. 2 Magnetic resonance imaging showed that the hepatic mass appeared to be hypointense (A) on T1-weighted image and hyperintense on both (B) T2weighted image and $(C)$ diffusionweighted image. 
Fig. 3 Macroscopic findings of the resected specimen. Image shows circumscribed, round, yellowish white, soft tumor.

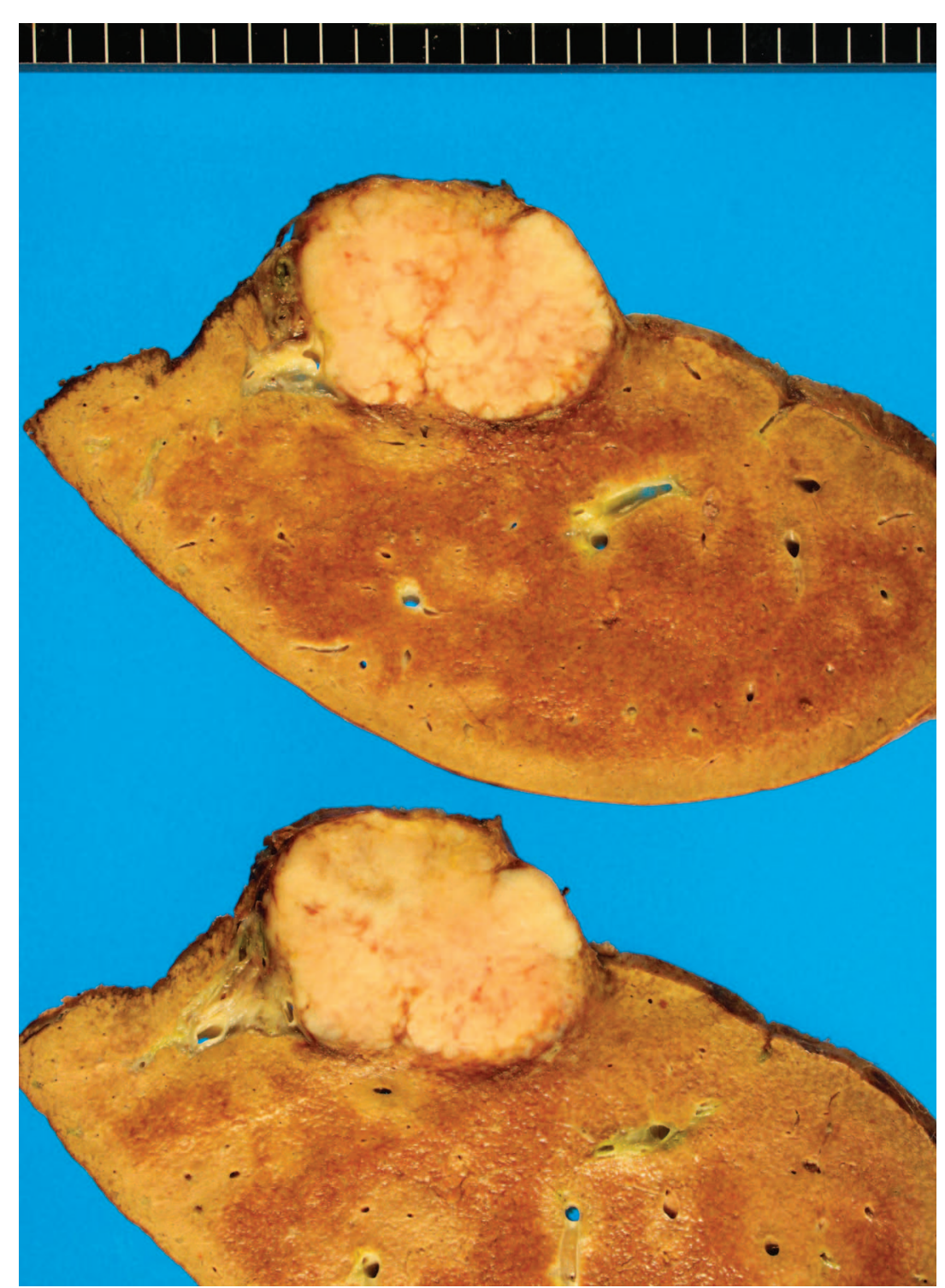

negative. $^{24}$ On the other hand, in ICC with LELC components, 38\% (6 of 16) of cases were EBV negative. These results suggest that the involvement of EBV genome integration in LELC depends on the origin of the LELC. Furthermore, Adachi et $a l^{7}$ reported that there are no obvious histopathologic differences between EBV-positive and EBV-negative ICC with LELC components. Therefore, the role of EBV in the tumorigenesis of LELC remains poorly understood and controversial, and lymphoepithelioma-like morphologic changes in cholangiocarcinoma can occur in both the presence and absence of EBV genome integration.

The present case was HCV positive, and several previous studies $^{30,31}$ have reported that HCV infec- tion plays an etiologic role in ICC; Lee et $a l^{32}$ indicated that there is a close relationship between the development of ICC and HBV infection. However, previous reports showed that only 31\% (5 of 16) of patients were HBV positive and 13\% (2 of 16) of patients were $\mathrm{HCV}$ positive. These findings suggest that the roles of $\mathrm{HBV}$ and $\mathrm{HCV}$ in the pathogenesis of ICC with LELC components are unclear and the further accumulation of studies is needed.

It has been reported that LELC of the stomach and lung has a better prognosis than other neoplasms of these sites. ${ }^{33,34}$ Similarly, the prognosis of ICC with LELC components seems to be better than that of the conventional type of cholangiocarcino- 


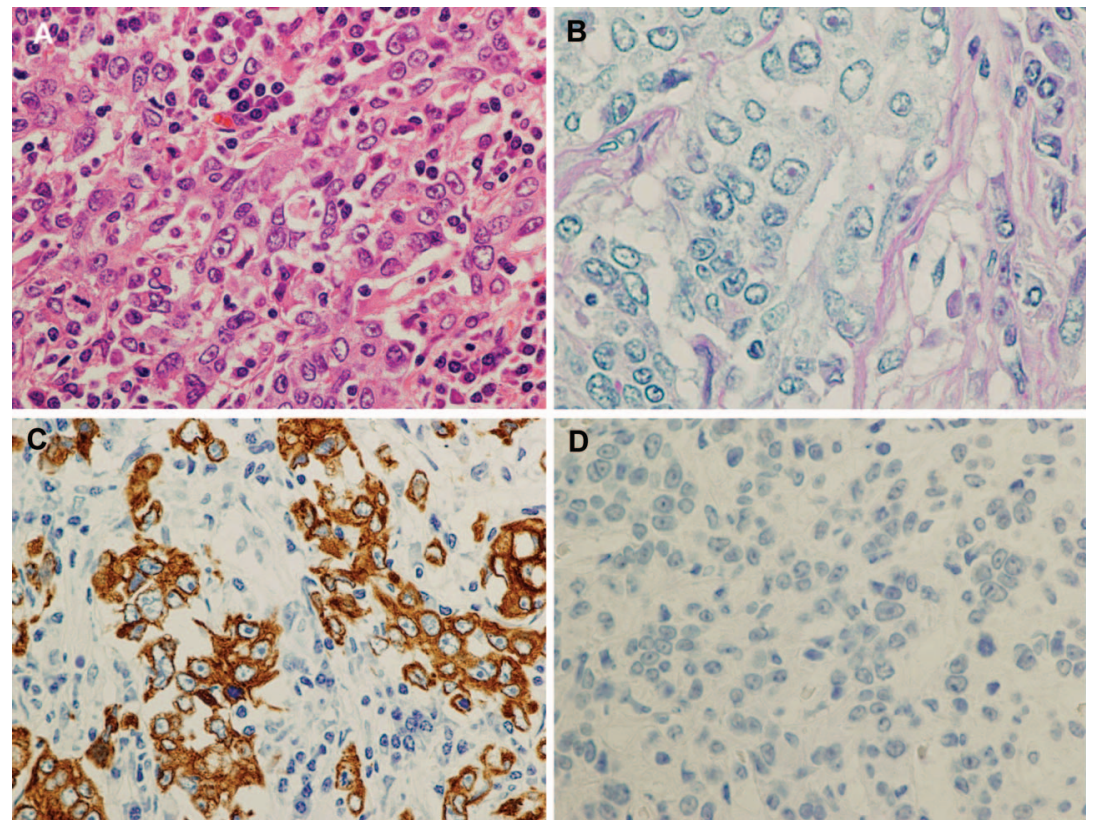

Fig. 4 Histologic specimen of liver tumor. (A) The neoplasm was mainly composed of large undifferentiated epithelial cells with vesicular nuclei, prominent nucleoli, indistinct cell borders, and heavy small lymphocytic infiltration. (B) Alcian blue staining was positive in epithelial lining. (C) Immunohistochemical staining demonstrated positivity for cytokeratin 19. (D) Immunohistochemical staining demonstrated negativity for glypican 3 . ma. ${ }^{8,25,35}$ There is no consensus on a standardized treatment strategy for LELC. In the previously reported cases, the patients all underwent surgical resection of their tumors. Lee ${ }^{5}$ reported that a case with metastasis to a para-aortic lymph node at the time of surgery underwent postoperative radiation and was still alive without recurrence 54 months after the surgery. The present patient also had lymph node metastases, but the metastatic lymph nodes were resected completely at the time of surgery, and the patient is alive without recurrence 20 months after the surgery. Cases of ICC with LELC components accompanied by lymph node metastases are extremely rare. Because there is limited information available regarding the prognosis and treatment of ICC with LELC components because of the limited number of reported cases, additional studies will be needed to clarify the clinicopathologic features of this disease.

Table 1 A summary of clinicopathologic features of intrahepatic cholangiocarcinoma with lymphoepithelioma-like carcinoma components

\begin{tabular}{|c|c|c|c|c|c|c|c|c|c|c|}
\hline Case no. & Source & $\begin{array}{l}\text { Age, } \\
\text { y/sex }\end{array}$ & Site & $\begin{array}{l}\text { Size, } \\
\mathrm{cm}\end{array}$ & EBV & HBV & $\mathrm{HCV}$ & LN & Outcome & $\begin{array}{c}\text { Follow-up } \\
\text { mo }\end{array}$ \\
\hline 1 & Hsu et $a l^{27}$ & $47 / \mathrm{F}$ & Left lobe & 10 & + & -- & - & Unknown & Died of disease & 48 \\
\hline 2 & Vortmeyer et $a l^{26}$ & $71 / \mathrm{F}$ & Portal hepatis & 5 & + & - & - & - & Alive with disease & 24 \\
\hline 3 & Kim et $a l^{10}$ & $64 / \mathrm{M}$ & Right lobe & 2 & - & - & + & - & Unknown & Unknown \\
\hline 4 & Ortiz et $a l^{4}$ & $19 / \mathrm{F}$ & Left lobe & 5.5 & + & - & - & - & Died of disease & 44 \\
\hline 5 & Chen $e t a l^{9}$ & $67 / \mathrm{F}$ & Right lobe & 5 & + & - & + & + & $\begin{array}{l}\text { Died, postoperative } \\
\text { pancreatitis }\end{array}$ & Unknown \\
\hline 6 & Chen et $a l^{9}$ & $41 / \mathrm{M}$ & Left lobe & 3 & - & + & - & - & No recurrence & 8 \\
\hline 7 & Jeng et $a l^{25}$ & $42 / \mathrm{M}$ & Right lobe & 3 & + & - & - & - & No recurrence & 96 \\
\hline 8 & Jeng et $a l^{25}$ & $67 / \mathrm{F}$ & Left lobe & 3 & + & - & - & - & No recurrence & 7 \\
\hline 9 & Jeng et $a l^{25}$ & $50 / \mathrm{M}$ & Right lobe & 4 & + & + & - & - & No recurrence & 16 \\
\hline 10 & Jeng et $a l^{25}$ & $50 / \mathrm{F}$ & Right lobe & 4 & + & + & - & - & No recurrence & 2 \\
\hline 11 & Szekely ${ }^{8}$ & $61 / \mathrm{M}$ & Unknown & 6 & - & - & - & - & No recurrence & 11 \\
\hline 12 & Huang et $a l^{3}$ & $60 / \mathrm{F}$ & Caudate lobe & 3.5 & + & + & - & - & No recurrence & 24 \\
\hline 13 & Adachi $e t a l^{7}$ & $64 / \mathrm{M}$ & Left lobe & 5.2 & - & - & - & - & No recurrence & 3 \\
\hline 14 & Henderson-Jackson et $a l^{2}$ & $63 / \mathrm{F}$ & Left lobe & 4 & + & - & - & - & No recurrence & 6 \\
\hline 15 & $\mathrm{Lee}^{5}$ & $79 / \mathrm{M}$ & Left lobe & 3.7 & - & + & - & + & No recurrence & 54 \\
\hline 16 & Hur et $a l^{6}$ & $57 / \mathrm{F}$ & Right lobe & 2 & - & - & - & - & No recurrence & 60 \\
\hline 17 & Our case & $65 / F$ & Caudate lobe & 6.4 & - & - & + & + & No recurrence & 20 \\
\hline
\end{tabular}

LN, lymph node metastasis. 


\section{References}

1. Iezzoni JC, Gaffey MJ, Weiss LM. The role of Epstein-Barr virus in lymphoepithelioma-like carcinomas. Am J Clin Pathol 1995;103(3):308-315

2. Henderson-Jackson E, Nasir NA, Hakam A, Nasir A, Coppola D. Primary mixed lymphoepithelioma-like carcinoma and intra-hepatic cholangiocarcinoma: a case report and review of literature. Int J Clin Exp Pathol 2010;3(7):736-741

3. Huang Y, Tsung JS, Lin CW, Cheng TY. Intrahepatic cholangiocarcinoma with lymphoepithelioma-like carcinoma component. Ann Clin Lab Sci 2004;34(4):476-480

4. Ortiz MR, Garijo G, Adrados M, Lopez-Bonet E, Acero D, Bernado L. Epstein-Barr virus-associated cholangiocarcinoma with lymphoepithelioma-like component. Int J Surg Pathol 2000;8(4):347-351

5. Lee W. Intrahepatic lymphoepithelioma-like cholangiocarcinoma not associated with epstein-barr virus: a case report. Case Rep Oncol 2011;4(1):68-73

6. Hur YH, Kim HH, Koh YS, Seoung JS, Cho CK. Lymphoepithelioma-like cholangiocarcinoma not associated with Epstein-Barr virus. ANZ J Surg 2011;81(9):652-653

7. Adachi S, Morimoto O, Kobayashi T. Lymphoepithelioma-like cholangiocarcinoma not associated with EBV. Pathol Int 2008; 58(1):69-74

8. Szekely E. Lymphoepithelioma-like cholangiocarcinoma (LELC) not associated with Epstein-Barr virus. Am J Surg Pathol 2001;25(11):1464-1466

9. Chen TC, Ng KF, Kuo T. Intrahepatic cholangiocarcinoma with lymphoepithelioma-like component. Mod Pathol 2001;14(5): 527-532

10. Kim YB, Park YN, Han JY, Hong KC, Hwang TS. Biliary lymphoepithelioma-like carcinoma not associated with Epstein-Barr virus. Arch Pathol Lab Med 1999;123(5):441-443

11. Tsai CC, Chen CL, Hsu HC. Expression of Epstein-Barr virus in carcinomas of major salivary glands: a strong association with lymphoepithelioma-like carcinoma. Hum Pathol 1996; 27(3):258-262

12. Leyvraz S, Henle W, Chahinian AP, Perlmann C, Klein G, Gordon RE, et al. Association of Epstein-Barr virus with thymic carcinoma. N Engl J Med 1985;312(20):1296-1299

13. Onizuka M, Doi M, Mitsui K, Ogata T, Hori M. Undifferentiated carcinoma with prominent lymphocytic infiltration (socalled lymphoepithelioma) in the trachea. Chest 1990;98(1): 236-237

14. Castro CY, Ostrowski ML, Barrios R, Green LK, Popper HH, Powell $\mathrm{S}$ et al. Relationship between Epstein-Barr virus and lymphoepithelioma-like carcinoma of the lung: a clinicopathologic study of 6 cases and review of the literature. Hum Pathol 2001;32(8):863-872

15. Chen PC, Pan CC, Hsu WH, Ka HJ, Yang AH. Epstein-Barr virus-associated lymphoepithelioma-like carcinoma of the esophagus. Hum Pathol 2003;34(4):407-411
16. Shibata D, Tokunaga M, Uemura Y, Sato E, Tanaka S, Weiss LM. Association of Epstein-Barr virus with undifferentiated gastric carcinomas with intense lymphoid infiltration: lymphoepithelioma-like carcinoma. Am J Pathol 1991;139(3):469-474

17. Dinney CP, Ro JY, Babaian RJ, Johnson DE. Lymphoepithelioma of the bladder: a clinicopathological study of 3 cases. J Urol 1993;149(4):840-841

18. Kohrenhagen N, Eck M, Holler S, Dietl J. Lymphoepitheliomalike carcinoma of the uterine cervix: absence of Epstein-Barr virus and high-risk human papilloma virus infection. Arch Gynecol Obstet 2008;277(2):175-178

19. Dietl J, Horny HP, Kaiserling E. Lymphoepithelioma-like carcinoma of the vagina: a case report with special reference to the immunophenotype of the tumor cells and tumor-infiltrating lymphoreticular cells. Int J Gynecol Pathol 1994;13(2):186189

20. Nemolato S, Fanni D, Naccarato AG, Ravarino A, Bevilacqua G, Faa G. Lymphoepitelioma-like hepatocellular carcinoma: a case report and a review of the literature. World J Gastroenterol 2008;14(29):4694-4696

21. Chen CJ, Jeng LB, Huang SF. Lymphoepithelioma-like hepatocellular carcinoma. Chang Gung Med J 2007;30(2):172177

22. Si MW, Thorson JA, Lauwers GY, DalCin P, Furman J. Hepatocellular lymphoepithelioma-like carcinoma associated with epstein barr virus: a hitherto unrecognized entity. Diagn Mol Pathol 2004;13(3):183-189

23. Emile JF, Adam R, Sebagh M, Marchadier E, Falissard B, Dussaix E et al. Hepatocellular carcinoma with lymphoid stroma: a tumour with good prognosis after liver transplantation. Histopathology 2000;37(6):523-529

24. Ishida M, Mori T, Shiomi H, Naka S, Tsujikawa T, Andoh A et al. Non-Epstein-Barr virus associated lymphoepithelioma-like carcinoma of the inferior common bile duct. World J Gastrointest Oncol 2011;3(7):111-115

25. Jeng YM, Chen CL, Hsu HC. Lymphoepithelioma-like cholangiocarcinoma: an Epstein-Barr virus-associated tumor. Am J Surg Pathol 2001;25(4):516-520

26. Vortmeyer AO, Kingma DW, Fenton RG, Curti BD, Jaffe ES, Duray PH. Hepatobiliary lymphoepithelioma-like carcinoma associated with Epstein-Barr virus. Am J Clin Pathol 1998; 109(1):90-95

27. Hsu HC, Chen CC, Huang GT, Lee PH. Clonal Epstein-Barr virus associated cholangiocarcinoma with lymphoepithelioma-like component. Hum Pathol 1996;27(8):848-850

28. Weiss LM, Movahed LA, Butler AE, Swanson SA, Frierson HF $\mathrm{Jr}$, Cooper $\mathrm{PH}$ et al. Analysis of lymphoepithelioma and lymphoepithelioma-like carcinomas for Epstein-Barr viral genomes by in situ hybridization. Am J Surg Pathol 1989; 13(8):625-631

29. Weinberg E, Hoisington S, Eastman AY, Rice DK, Malfetano J, Ross JS. Uterine cervical lymphoepithelial-like carcinoma: 
absence of Epstein-Barr virus genomes. Am J Clin Pathol 1993; 99(2):195-199

30. El-Serag HB, Engels EA, Landgren O, Chiao E, Henderson L, Amaratunge $\mathrm{HC}$ et al. Risk of hepatobiliary and pancreatic cancers after hepatitis $C$ virus infection: a population-based study of U.S. veterans. Hepatology 2009;49(1):116-123

31. Yamamoto S, Kubo S, Hai S, Uenishi T, Yamamoto T, Shuto Tet al. Hepatitis C virus infection as a likely etiology of intrahepatic cholangiocarcinoma. Cancer Sci 2004;95(7):592-595

32. Lee TY, Lee SS, Jung SW, Jeon SH, Yun SC, Oh HC et al. Hepatitis B virus infection and intrahepatic cholangiocarcinoma in Korea: a case-control study. Am J Gastroenterol 2008; 103(7):1716-1720
33. Chen FF, Yan JJ, Lai WW, Jin YT, Su IJ. Epstein-Barr virusassociated nonsmall cell lung carcinoma: undifferentiated "lymphoepithelioma-like" carcinoma as a distinct entity with better prognosis. Cancer 1998;82(12):2334-2342

34. Matsunou H, Konishi F, Hori H, Ikeda T, Sasaki K, Hirose Y et al. Characteristics of Epstein-Barr virus-associated gastric carcinoma with lymphoid stroma in Japan. Cancer 1996; 77(10):1998-2004

35. El Rassi ZE, Partensky C, Scoazec JY, Henry L, Lombard-Bohas C, Maddern G. Peripheral cholangiocarcinoma: presentation, diagnosis, pathology and management. Eur J Surg Oncol 1999; 25(4):375-380 